Provided for non-commercial research and education use. Not for reproduction, distribution or commercial use.

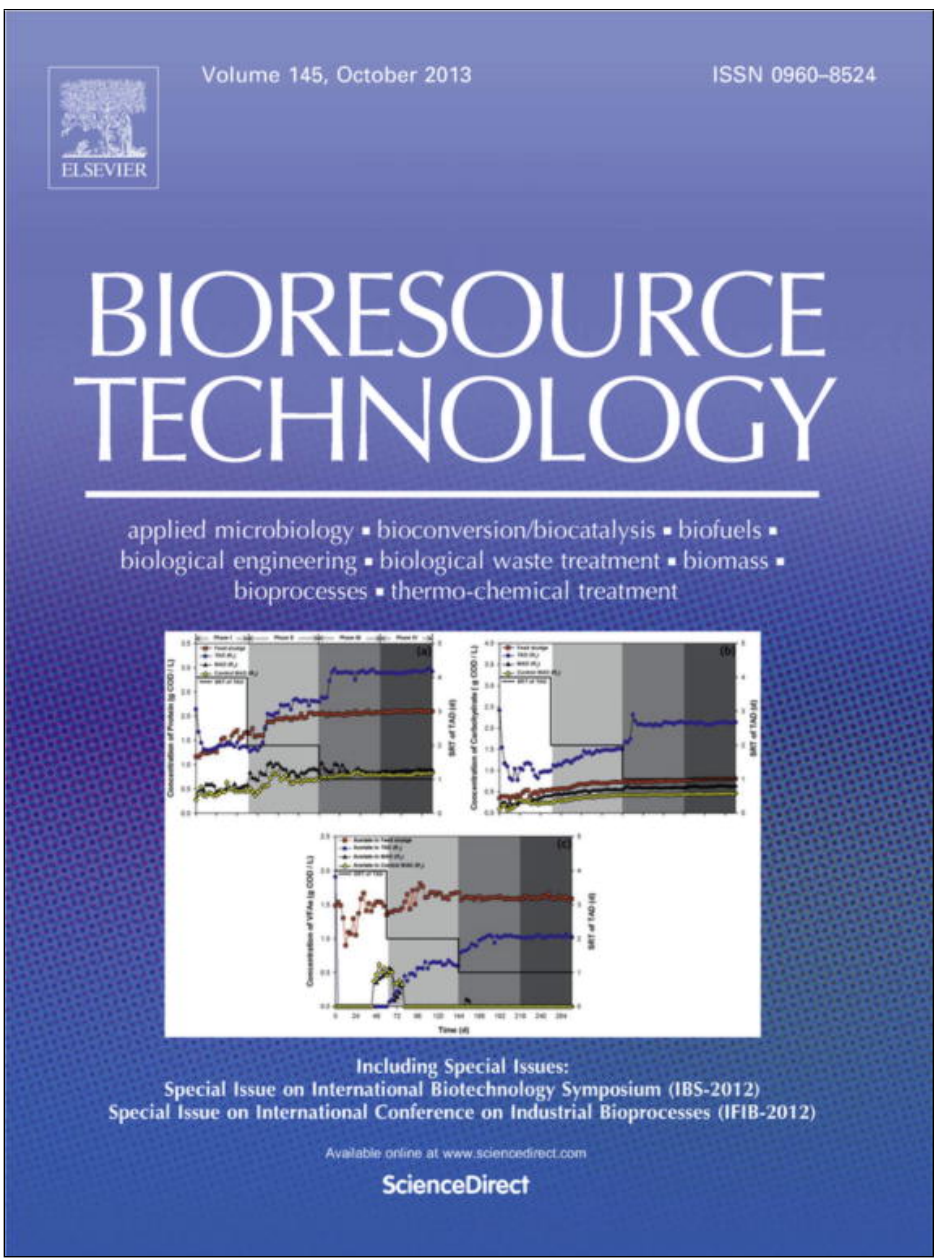

This article appeared in a journal published by Elsevier. The attached copy is furnished to the author for internal non-commercial research and education use, including for instruction at the authors institution and sharing with colleagues.

Other uses, including reproduction and distribution, or selling or licensing copies, or posting to personal, institutional or third party websites are prohibited.

In most cases authors are permitted to post their version of the article (e.g. in Word or Tex form) to their personal website or institutional repository. Authors requiring further information regarding Elsevier's archiving and manuscript policies are encouraged to visit:

http://www.elsevier.com/authorsrights 


\title{
Bioethanol production from Yarrowia lipolytica Po1g biomass
}

\author{
Yeshitila A. Tsigie ${ }^{a}$, Chung-Hsan $\mathrm{Wu}^{a}$, Lien Huong Huynh ${ }^{\mathrm{b}}$, Suryadi Ismadji ${ }^{\mathrm{c}}$, Yi-Hsu Ju ${ }^{\mathrm{a}, *}$ \\ ${ }^{a}$ Department of Chemical Engineering, National Taiwan University of Science and Technology, 43 Keelung Rd., Sec. 4, Taipei 106-07, Taiwan \\ ${ }^{\mathrm{b}}$ Department of Chemical Engineering, Cantho University, 3-2 Street, Cantho City, Viet Nam \\ ${ }^{\mathrm{c}}$ Department of Chemical Engineering, Widya Mendala Catholic University, Surabaya, Indonesia
}

\section{A R T I C L E I N F O}

\section{Article history:}

Available online 29 November 2012

\section{Keywords:}

Acid hydrolysis

Bioethanol

Glucose

Subcritical water

Yarrowia lipolytica Po1g

\begin{abstract}
A B S T R A C T
Bioethanol production from the yeast Yarrowia lipolytica biomass was studied. The effects of temperature $\left(90-150{ }^{\circ} \mathrm{C}\right)$ and $\mathrm{H}_{2} \mathrm{SO}_{4}$ concentration $(2-15 \% \mathrm{w} / \mathrm{w})$ on the saccharification of biomass at a hydrolysis time of $1 \mathrm{~h}$ were investigated. A maximum glucose concentration of $35.89 \mathrm{~g} / \mathrm{L}$ can be produced from defatted biomass using $6 \% \mathrm{H}_{2} \mathrm{SO}_{4}$ at $120^{\circ} \mathrm{C}$. Subcritical water (SCW) pretreatment has negligible effect on maximizing glucose yield. Only $14.53 \mathrm{~g} / \mathrm{L}$ glucose can be produced using $6 \% \mathrm{H}_{2} \mathrm{SO}_{4}$ at $120{ }^{\circ} \mathrm{C}$ if undefatted biomass was used. The highest ethanol concentration achieved was $13.39 \mathrm{~g} / \mathrm{L}$ with a corresponding ethanol yield of $0.084 \mathrm{~g} / \mathrm{g}$ dry biomass $(0.38 \mathrm{~g}$ ethanol $/ \mathrm{g}$ glucose).
\end{abstract}

(c) 2012 Elsevier Ltd. All rights reserved.

\section{Introduction}

Increasing concern for rapid population growth, industrialization, the security of oil supply and the negative impact of fossil fuels on environment have put pressure on society to find renewable fuel alternatives. Even though different renewable energy alternatives have been suggested, the most commonly practiced and environmentally friendly renewable fuel today is ethanol.

Earlier researches were basically focused on ethanol production from sugar or grain. Conventionally, bioethanol is produced from the fermentation of starchy materials or sucrose-containing feedstocks such as corn and sugar cane. The yields of bioethanol from corn and sugar are high and the techniques are mature, however, this technology increases the risk of causing global food shortage (Chen et al., 2010). Consequently, research efforts have become more focused on low-cost lignocellulosic feedstock originating mainly from agricultural and forest residues along with herbaceous materials and municipal wastes.

Lignocellulosics are the most abundant biomass available on earth, comprising mainly of cellulose and hemicellulose. Fermentable sugars such as glucose and xylose can be released from lignocellulosics (Lebeau et al., 1997). Lignocellulosic biomass conversion to bioethanol has long been pursued for its potential to provide an alternative renewable energy source that can substitute fossil fuels. It was suggested that future large-scale use of ethanol will most certainly have to be based on production from lignocellulosic materials. Lignocellulosic substances such as agricultural wastes

\footnotetext{
* Corresponding author. Tel.: +886 227376612; fax: +886 227376644.

E-mail address: yhju@mail.ntust.edu.tw (Y.-H. Ju).
}

are attractive feedstocks for bioethanol production since they are cost effective, renewable and abundant (Sarkar et al., 2012).

Wastes from vegetables were also used as feedstocks for a diluted acid hydrolysis process using sulfuric acid as a catalytic. Sugars in fresh and processed vegetable wastes (residues from tomato, red pepper, beans, artichoke, lentils and chickpeas) are widely available and easily obtainable and they can be considered as potential feedstocks for bioethanol production (del Campo et al., 2006). According to a review, the utilization of algal biomass for bioethanol production is undoubtedly a sustainable and ecofriendly approach for renewable biofuel production suggesting that more attention is needed for the efficient use of these easily cultivable microorganisms to generate bioethanol (John et al., 2011).

One of the major challenges in bioethanol production is to optimize the integration of process engineering, fermentation technology, enzyme engineering and metabolic engineering (Hahn-Hägerdal et al., 2006). The pretreatment step has been recognized as a technological bottleneck for the cost-effective development of bioprocesses from lignocellulosic materials (Conde-Mejía et al., 2012). It has been reported that the extraction and saccharification of easily fermentable carbohydrates from different sources such as weed, grasses, saw dust, municipal solid waste, waste paper or pulp and paper mill wastes is the necessary step in the production of bioethanol. Cell disruption is often required to recover the intracellular products of microalgae, such as oil and starch for biodiesel and ethanol production, respectively, as well as added-value compounds (Brennan and Owende, 2010).

Proper pretreatment can increase concentrations of fermentable sugars after enzymatic saccharification, thereby improving the efficiency of the whole process. Conversion of glucose as well 
as xylose to ethanol needs some new fermentation technologies, to make the whole process cost effective (Sarkar et al., 2012). Different methods of biomass pretreatment that have been studied include steam explosion of wheat straw (Bellido et al., 2011), acid hydrolysis of wood biomass and ionic liquids-based chemical hydrolysis of Chlorella biomass (Zhou et al., 2011). A previous study showed that subcritical water assisted pretreatment can increase the amount of extractable lipids from yeast cells by two fold (Tsigie et al., 2012a).

For algal cell wall disruption, both physical and chemical methods have been tested. Chemical lysis is a method where chemical agents (acid or alkaline) must to be added in order to hydrolyze biomass into its constituent molecules (Lee et al., 2010). After the disruption, carbohydrates are released from the intracellular medium requiring further processing to obtain monosaccharides (Brennan and Owende, 2010).

Currently, biomass to ethanol conversion technology relies mainly on chemical and enzymatic treatments. Chemical hydrolysis of biomass with dilute sulfuric acid has long been recognized as a critical step for removing the hemicellulosic fraction from lignocellulosic substrate to economize the biological conversion of cellulosic biomass to ethanol. However, the pentose sugar-rich acid hydrolysate also contains toxic byproducts such as furfural, hydroxy methyl furfural (HMF) and phenolics, which significantly affect yeast cell metabolism during fermentation (Chandel et al., 2007; Palmqvist and Hahn-Hägerdal, 2000). Although various detoxification methods have been investigated for the removal of fermentation inhibitory compounds (Chandel et al., 2007; Palmqvist and Hahn-Hägerdal, 2000), overliming, activated charcoal adsorption and base neutralization methods are widely used (Gupta et al., 2009; Miyafuji et al., 2003; Tsigie et al., 2011).

The ascomycetous Yarrowia lipolytica is one of the nonconventional yeasts used as a model for the study of protein secretion, dimorphism, hydrophobic substrate degradation, biolipid production and other related fields (Fickers et al., 2011). Previous studies about lipid and biodiesel production from this yeast biomass also showed its potential applications in biofuel research (Tsigie et al., 2012a,b, 2011).

In this study, Y. lipolytica Po1g biomass was used as a feedstock for glucose and bioethanol production. In acid hydrolysis and subcritical water pretreatment, the effects of temperature, acid concentration and biomass loading on the amount of glucose were investigated and the optimal conditions were determined.

\section{Methods}

\subsection{Materials}

Y. lipolytica Po1g was obtained from Yeastern Biotech Company (Taipei, Taiwan). Ethanol Red ${ }^{\circledR}$ Saccharomyces cerevisiae was purchased from Fermentis (Marcq en Baroeul Cedex, France).

Ethanol (95\%) and methanol (HPLC grade, 99.9\% purity) were supplied by Echo, Taiwan. Acetonitrile (99.9\% purity, HPLC grade) and furfural (99\% purity) were obtained from Sigma-Aldrich (St. Louis, USA) while 5-hydroxymethylfurfural (5-HMF, 98\% purity) was purchased from Alfa Aesar Company (Lancaster, UK). Agar pure powder, anhydrous ACS reagent grade, $\mathrm{D}(+)$-glucose, $\mathrm{D}(+)$-xylose (99\% purity), $\mathrm{L}(+)$-arabinose (99\% purity), potassium hydroxide pellets, sodium hydroxide pellets, dinitrosalicylic acid (99\% purity) and potassium sodium tartrate ( $99 \%$ purity) were obtained from Acros Organics (NJ, USA). Glacial acetic acid (99.7\% purity) was bought from Mallinckrodt (Austin, USA) and sulfuric acid (98\% purity) was obtained from Scharlau (Barcelona, Spain). Peptone and yeast extract as nitrogen sources for microbial growth were supplied by Bacto (Mt Pritchard, Australia). Different types of filter papers were purchased from Advantec (Dublin, USA).

\subsection{Y. lipolytica Po1g biomass production}

Y. lipolytica Po1g cells were placed on a sterilized agar plate containing a medium composed of $10 \mathrm{~g} / \mathrm{L}$ yeast extract, $20 \mathrm{~g} / \mathrm{L}$ peptone, $20 \mathrm{~g} / \mathrm{L}$ glucose, and $20 \mathrm{~g} / \mathrm{L}$ agar. Then the plate was incubated at $26{ }^{\circ} \mathrm{C}$ over night and stored in a refrigerator at $4{ }^{\circ} \mathrm{C}$ until use. A $24 \mathrm{~h}$ small scale culture was prepared by inoculating a single colony of $Y$. lipolytica Po1g into a medium containing yeast extract $(10 \mathrm{~g} / \mathrm{L})$, peptone $(20 \mathrm{~g} / \mathrm{L})$ and glucose $(20 \mathrm{~g} / \mathrm{L})$. After that, a large scale culture was prepared by inoculating a $24 \mathrm{~h}$ culture seed into an Erlenmeyer flask containing $250 \mathrm{~mL}$ YPD medium made of yeast extract $(10 \mathrm{~g} / \mathrm{L})$, peptone $(20 \mathrm{~g} / \mathrm{L})$ and glucose $(20 \mathrm{~g} / \mathrm{L})$ with an inoculum to YPD medium ratio of $1-10(\mathrm{v} / \mathrm{v})$. The culturing was carried out at $26^{\circ} \mathrm{C}$ in an orbital shaker incubator. Cell mass was harvested by centrifugation. The harvested cells were washed with deionized (DI) water and dried in a freeze dryer (Free Zone 2.5 Benchtop model 7670520, Labconco, USA). All media and flasks were autoclaved at $121^{\circ} \mathrm{C}$ for $40 \mathrm{~min}$ before use.

\subsection{Lipid extraction and cell wall composition determination}

The dried biomass was ground into powder by using an agate mortar and pestle. For lipid extraction, the biomass powder was put in a cellulosic thimble and placed in a Soxhlet extractor. Extraction was carried out for $10 \mathrm{~h}$ using $350 \mathrm{~mL}$ methanol and hexane $(1: 1 \mathrm{v} / \mathrm{v})$. The residue after extraction was dried in an oven at $50{ }^{\circ} \mathrm{C}$. Cellulose and hemicellulose contents of the dried biomass were determined according to the method of the National Renewable Energy Laboratory (Sluiter et al., 2008).

\subsection{Subcritical water (SCW) pretreatment of biomass}

Freeze-dried defatted biomass sample $(1.0 \mathrm{~g})$ was put in a subcritical reactor and $10 \mathrm{~mL}$ DI water was added. Nitrogen was introduced into the reactor until pressure in the reactor reached 20 bar. The mixture in the reactor was then heated to a pre-determined temperature $\left(100,120,150\right.$ or $\left.180^{\circ} \mathrm{C}\right)$. After $1 \mathrm{~h}$, pressure in the reactor was reduced to ambient pressure and the reactor was then cooled down to room temperature. Solid residue in the mixture was collected and freeze-dried for 2 days and stored at $4{ }^{\circ} \mathrm{C}$ for further study.

\subsection{Acid hydrolysis of dry biomass}

The dried biomass was hydrolyzed with different biomass to sulfuric acid ratios $(1: 8,1: 10,1: 12$ and $1: 15 \mathrm{w} / \mathrm{w})$ at different temperatures $\left(90,100,121,135\right.$ and $\left.150{ }^{\circ} \mathrm{C}\right)$ and different acid concentrations (2, 4, 6, 10 and $15 \mathrm{wt} . \%)$. The reaction time was set at $1 \mathrm{~h}$.

\subsection{Neutralization of hydrolysate}

The biomass acid hydrolysate was constantly stirred at room temperature while $\mathrm{KOH}(1 \mathrm{M})$ was slowly added until $\mathrm{pH}$ of the solution was 6.0. Then the solution was centrifuged to remove precipitate. The supernatant was then filtered through a $0.22 \mu \mathrm{m}$ PVDF syringe filter (Tokyo, Japan) and stored at $4{ }^{\circ} \mathrm{C}$.

\subsection{Ethanol production}

Ethanol $\operatorname{Red}^{\circledR}$ S. cerevisiae cells were maintained on a sterilized YPD agar plate containing yeast extract $(10 \mathrm{~g} / \mathrm{L})$, peptone $(20 \mathrm{~g} / \mathrm{L})$, glucose $(20 \mathrm{~g} / \mathrm{L})$ and agar $(20 \mathrm{~g} / \mathrm{L})$. The plate was then incubated in an orbital shaker incubator at $37^{\circ} \mathrm{C}$ for $24 \mathrm{~h}$ and then stored at 
$4^{\circ} \mathrm{C}$. A single colony of S. cerevisiae was incubated in a YPD medium at $37^{\circ} \mathrm{C}$ for $1 \mathrm{~h}$ and then transferred (inoculum to medium ratio $=1: 10, v / v)$ to a flask containing a medium composed of the hydrolysate (with total glucose concentration $=35.89 \mathrm{~g} / \mathrm{L}$ ), peptone $(20 \mathrm{~g} / \mathrm{L})$ and yeast extract $(10 \mathrm{~g} / \mathrm{L})$. Then, it was incubated in an orbital shake incubator at $37^{\circ} \mathrm{C}$. During fermentation, sample was taken for analysis of glucose and ethanol concentration at $0,3,6,9,12,24$ and $48 \mathrm{~h}$.

\subsection{Sugar analysis}

Concentrations of D-glucose, D-xylose and L-arabinose in the hydrolysate were determined by a HPLC equipped with a PU1580 pump (Jasco, Japan), a DG-4400 degasser (Phenomenex, USA), an Alltech 2000 ELSD detector (Alltech, USA) and a Zorbax $\mathrm{NH}_{2}$ column $(5 \mu \mathrm{m}, 250 \times 4.6 \mathrm{~mm}$, Agilent Technologies, USA $)$. The sample was diluted appropriately with DI-water, filtered through a $0.22 \mu \mathrm{m}$ PVDF syringe filter and then injected into the HPLC. Temperature of the ELSD detector and nitrogen flow rate were $80^{\circ} \mathrm{C}$ and $2 \mathrm{~mL} / \mathrm{min}$, respectively. The column temperature was $25^{\circ} \mathrm{C}$. A mixture of acetonitrile and water $(80: 20, \mathrm{v} / \mathrm{v})$ was employed as the mobile phase with a flow rate of $1 \mathrm{~mL} / \mathrm{min}$. The injection volume was $25 \mu \mathrm{L}$. The concentrations of D-glucose, D-xylose and L-arabinose were calculated by using calibration curves obtained from standard solutions of these compounds.

The amount of total reducing sugars in the hydrolysates was measured by the Miller method (Miller, 1959) based on a colorimetric reaction between sugars and dinitrosalicylic acid. The samples were monitored at $540 \mathrm{~nm}$ using a spectrophotometer (V-550, Jasco, Japan). The concentration of total sugars was calculated by using calibration curve obtained from standard D-glucose solution.

\subsection{Inhibitor analysis}

Concentrations of 5-hydroxymethylfurfural (5-HMF) and furfural in the hydrolysate were determined by a HPLC equipped with a PU-2089 pump (Jasco, Japan) combined with a degasser, an UV-2077 detector (Jasco, Japan) and a Luna C-18 column ( $5 \mu \mathrm{m}$, $250 \times 4.6 \mathrm{~mm}$, Phenomenex, USA). The sample was diluted appropriately with DI-water, filtered through a $0.22 \mu \mathrm{m}$ PVDF syringe filter and then injected into the HPLC under a column temperature of $25^{\circ} \mathrm{C}$. Acetonitrile: water: acetic acid $(11: 88: 1, \mathrm{v} / \mathrm{v} / \mathrm{v})$ with a flow rate of $0.8 \mathrm{~mL} / \mathrm{min}$ was the mobile phase. The injection volume was $25 \mu \mathrm{L}$. The absorption wavelength was $276 \mathrm{~nm}$. The concentrations of 5-HMF and furfural were calculated by using calibration curves obtained from standard solutions of these compounds.

\subsection{Ethanol analysis}

The concentration of ethanol was determined by a GC 14B (Shimadzu, Japan) with a FID detector and a Stabilwax ${ }^{\circledR}$-DA column (fused silica, polar phase; crossbond $^{\circledR}$ carbowax $^{\circledR}$ polyethylene glycol, Restec, USA). The sample was filtered through a $0.22 \mu \mathrm{m}$ PVDF syringe filter and then injected into the GC. The column temperature was $40^{\circ} \mathrm{C}$ while the injector and detector temperatures were set at $200{ }^{\circ} \mathrm{C}$ and $250^{\circ} \mathrm{C}$, respectively. The injection volume was $1 \mu \mathrm{L}$. The concentration of ethanol was determined by using a calibration curve obtained from standard ethanol solutions.

\section{Results and discussion}

\subsection{Composition of defatted Y. lipolytica Po1g biomass}

Lignocellulosic composition of biomasses differs depending on the type and origin of the biomass. Plant cellulose and hemicellu- lose contents range from $25 \%$ to $58 \%$ and $10 \%$ to $35 \%$, respectively (Mohamed et al., 2010; Schädel et al., 2010). In this study, cellulose and hemicellulose contents in the dried, defatted yeast biomass was found to be 43.09 and 2.81 wt.\%, respectively. It has also been reported that carbohydrate composition of microalgae varies from strain to strain and a significant amount of carbohydrates was found to be glucose suggesting the species with a high potential for use as a fermentation feedstock for bioethanol production. Green algae species have $20-40$ wt.\% cellulose and $20-50$ wt.\% hemicellulose suggesting that different species have different lignocellulose compositions (Balat, 2011). In this study, the high cellulose content of $Y$. lipolytica biomass relative to its lignocellulose content suggests the existence of high concentration of glucose relative to pentose sugars upon hydrolysis.

\subsection{Effect of hydrolysis temperature}

An increase in temperature in hydrolysis results in higher reaction rate, hence shorter time to reach high glucose concentration. But if the temperature is too high, sugar will be degraded into compounds such as 5-HMF and furfural that are toxic for S. cerevisiae in fermentation. Fig. 1 shows the effect of temperature on the hydrolysis of biomass.

It can be seen that glucose is the most abundant sugar in the hydrolysate. Both xylose and arabinose concentrations are very low $(0.90 \mathrm{~g} / \mathrm{L}$ and $1.43 \mathrm{~g} / \mathrm{L}$, respectively $)$. Hence total sugar concentration is almost equivalent to glucose concentration in the hydrolysate. Hydrolysis at higher temperature $\left(120^{\circ} \mathrm{C}\right)$ yielded higher glucose concentration $(35.89 \mathrm{~g} / \mathrm{L})$ than those obtained at lower temperatures $\left(1.37 \mathrm{~g} / \mathrm{L}\right.$ and $10.89 \mathrm{~g} / \mathrm{L}$ for $90^{\circ} \mathrm{C}$ and $100{ }^{\circ} \mathrm{C}$, respectively). Too high temperature $\left(135^{\circ} \mathrm{C}\right.$ and $\left.150^{\circ} \mathrm{C}\right)$ not only resulted in reduced glucose concentrations $(27.58 \mathrm{~g} / \mathrm{L}$ and $10.98 \mathrm{~g} / \mathrm{L}$, respectively) but also increased the inhibitor concentrations. 5-HMF and furfural are the decomposition products of hexoses and pentoses, respectively. 5-HMF and furfural concentrations are very low at temperature up to $100^{\circ} \mathrm{C}$. At $120^{\circ} \mathrm{C}, \mathrm{HMF}$ and furfural concentrations are $0.24 \mathrm{~g} / \mathrm{L}$ and $0.17 \mathrm{~g} / \mathrm{L}$, respectively, but increased to $1.12 \mathrm{~g} / \mathrm{L}$ and $0.43 \mathrm{~g} / \mathrm{L}$, respectively at $135^{\circ} \mathrm{C}$. However, at $150^{\circ} \mathrm{C}$, 5-HMF and furfural concentrations decreased to $0.75 \mathrm{~g} / \mathrm{L}$ and $0.35 \mathrm{~g} / \mathrm{L}$, respectively while the concentrations of other unknown products increased as observed from HPLC results (data not shown). Based on total sugar concentration and inhibitor concentration, $120^{\circ} \mathrm{C}$ was chosen as the optimum hydrolysis temperature. It was reported that at fixed acid concentration and reaction time, glucose concentration decreased when temperature is higher than the optimum temperature due to the degradation of glucose (Palmarola-Adrados et al., 2005). Similar results was obtained when G. amansii (a macroalgae) was used in the sulfuric acid catalyzed hydrolysis (Jeong et al., 2012).

\subsection{Effect of sulfuric acid concentration}

It was observed that increasing acid concentration resulted in higher glucose concentration but degradation also occurred when acid concentration was too high.

Fig. 2 shows the effect of acid concentration on the hydrolysis of defatted biomass. A maximum glucose concentration of $35.89 \mathrm{~g} / \mathrm{L}$ was obtained when $6 \%$ sulfuric acid was used. At acid concentration higher than $6 \%$, not only lower glucose concentration was obtained but an increment in inhibitor concentration was observed. 5 -HMF was not detected when using $2 \%$ sulfuric acid. At $6 \%$, the concentration of 5-HMF and furfural were $0.24 \mathrm{~g} / \mathrm{L}$ and $0.19 \mathrm{~g} / \mathrm{L}$, respectively. When acid concentration was raised to $10 \%$, the concentration of HMF and furfural became $0.30 \mathrm{~g} / \mathrm{L}$ and $0.24 \mathrm{~g} / \mathrm{L}$, respectively. 


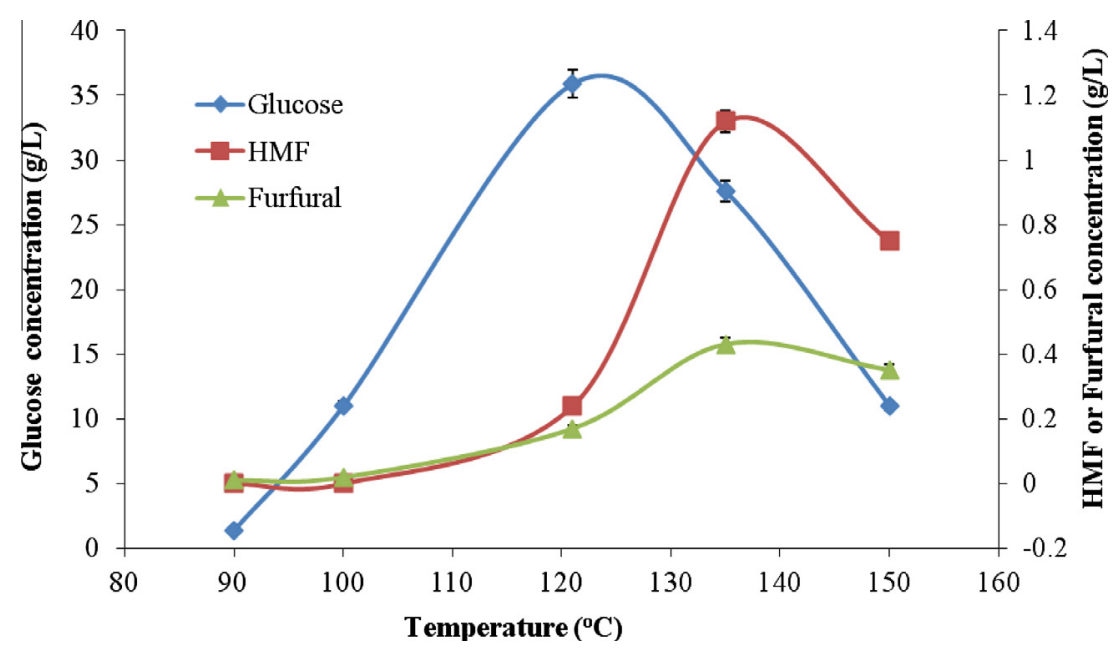

Fig. 1. Effect of temperature on glucose, 5 -HMF and furfural concentrations. Reaction conditions: $6 \%$ sulfuric acid, $1 \mathrm{~h}$, biomass to acid solution ratio $1: 10$ (w/w). Defatted biomass without SCW pretreatment was used.

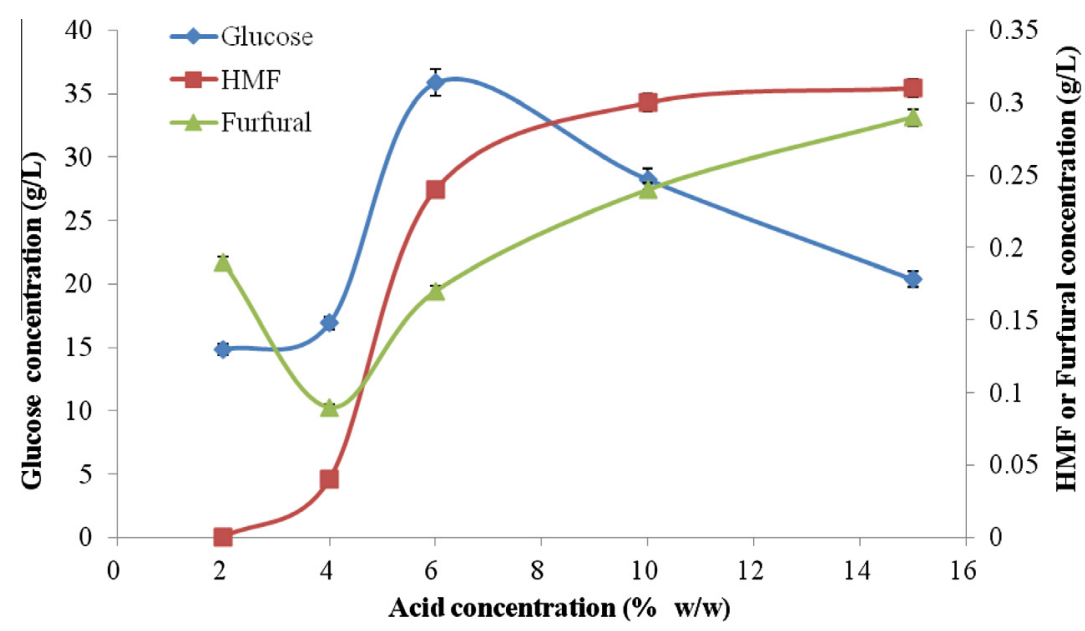

Fig. 2. Effect of sulfuric acid concentration on glucose, 5-HMF and furfural concentrations. Reaction conditions: $120{ }^{\circ} \mathrm{C}, 1 \mathrm{~h}$, biomass to acid solution ratio $1: 10$ (w/w). Defatted biomass without SCW pretreatment was used.

A previous study reported that in the hydrolysis of sugarcane bagasse, increasing $\mathrm{HCl}$ concentration from $1 \%$ to $2.5 \%$ increased the total sugar concentration in the hydrolysate from 9.89 to $21.38 \mathrm{~g} / \mathrm{L}$ (Tsigie et al., 2011). However, when acid concentration was raised to $3 \%$, total sugar concentration obtained decreased to $17.71 \mathrm{~g} / \mathrm{L}$. This was caused by the decomposition of hexose to 5HMF and pentose to furfural. The highest 5-HMF and furfural concentrations were obtained ( 0.83 and $0.15 \mathrm{~g} / \mathrm{L}$, respectively) when $3 \% \mathrm{HCl}$ was used.

In the hydrolysis of $G$. amansii (a macroalgae) biomass, increasing sulfuric acid concentration from $3 \%$ to $4 \%$ resulted in sharp increases of glucose decomposition products such as 5-HMF, formic acid and levulinic acid by $23.6 \%, 64.7 \%$ and $51.2 \%$, respectively while glucose yield decreased by $12.5 \%$ (Jeong et al., 2011).

\subsection{Effect of biomass loading}

A change of biomass to acid solution ratio from 1:8 to $1: 12$ did not result in significant differences in the amount of glucose produced. However, at a ratio of 1:15, glucose concentration decreased significantly as shown in Fig. 3. Similar results were reported when

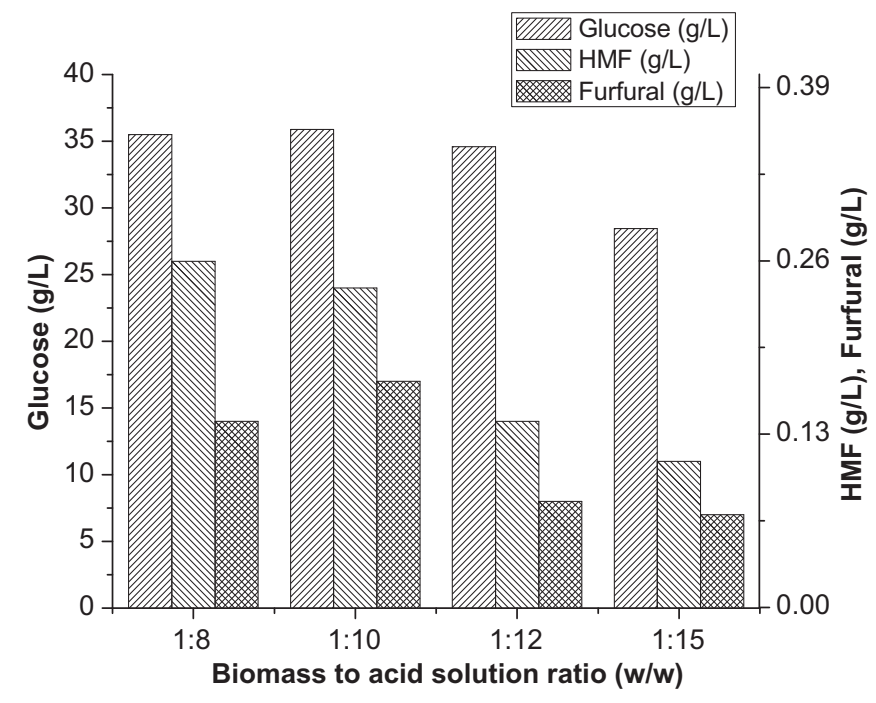

Fig. 3. Effect of biomass to acid solution ratio on glucose, HMF and Furfural concentrations. Reaction conditions: $6 \%$ sulfuric acid, $120^{\circ} \mathrm{C}, 1 \mathrm{~h}$. Defatted biomass without SCW pretreatment was used. 




Fig. 4. Effect of SCW pretreatment temperature on glucose, $5-\mathrm{HMF}$ and furfural concentrations. Reaction conditions: biomass to acid solution ratio $1: 10,120{ }^{\circ} \mathrm{C}, 6 \%$ sulfuric acid, $1 \mathrm{~h}$. Defatted biomass was used.

microalgal biomass was hydrolyzed through acid pre-treatment (Harun and Danquah, 2011).

From Figs 1-3, it can be observed that the effect of temperature on glucose concentration as well as concentration of inhibitors is more pronounced than the effect of acid concentration. The results are similar to those reported in the hydrolysis of potato skin using phosphoric acid as the catalyst in which it was found that degradation of sugars was mainly affected by temperature (Lenihan et al., 2010).

Under the optimum conditions (biomass to acid solution ratio $1: 10$, hydrolysis temperature $120^{\circ} \mathrm{C}$, sulfuric acid concentration $6 \%$ ), the hydrolysate obtained in this study contained $35.89 \mathrm{~g} / \mathrm{L}$ glucose, $0.24 \mathrm{~g} / \mathrm{L}$ HMF and $0.17 \mathrm{~g} / \mathrm{L}$ furfural.

\subsection{Effect of SCW pretreatment}

Fig. 4 shows the effect of temperature during SCW pretreatment on acid-catalyzed hydrolysis of defatted biomass. Glucose concentration increased with temperature from 100 to $120^{\circ} \mathrm{C}$. However, further increase in temperature resulted in decreasing glucose concentration. It was found that SCW pretreatment did give higher glucose concentration while inhibitor concentration was much higher than that without SCW pretreatment.

It was reported that glucose recovery of enzymatic hydrolysis was enhanced if oil palm fronds were SCW pretreated (Goh et al., 2010). But according to the results of this study, SCW pretreatment was unsuccessful for biomass of $Y$. lipolytica. SCW pretreatment is

Table 1

Effect of lipid extraction on the concentrations of glucose, HMF and furfural. Reactions were carried out at $120^{\circ} \mathrm{C}, 1 \mathrm{~h}$ and a solid to liquid ratio of $1: 10(\mathrm{~g} / \mathrm{mL})$ on biomass without SCW pretreatment.

\begin{tabular}{lccc}
\hline \multirow{2}{*}{$\begin{array}{c}\text { Acid concentration } \\
(\% \mathrm{w} / \mathrm{w})\end{array}$} & \multicolumn{3}{l}{ Concentration $(\mathrm{g} / \mathrm{L})$} \\
\cline { 2 - 4 } & Glucose & HMF & Furfural \\
\hline 2 & $7.51 \pm 0.82^{\mathrm{a}}$ & $0.013 \pm 0.006$ & $0.167 \pm 0.012$ \\
& $14.86 \pm 0.25^{\mathrm{b}}$ & $\mathrm{ND}$ & $0.19 \pm 0.00$ \\
4 & $13.84 \pm 1.78$ & $0.093 \pm 0.015$ & $0.097 \pm 0.006$ \\
& $16.92 \pm 1.20$ & $0.04 \pm 0.00$ & $0.09 \pm 0.01$ \\
6 & $14.53 \pm 2.17$ & $0.160 \pm 0.000$ & $0.123 \pm 0.005$ \\
& $35.89 \pm 1.90$ & $0.24 \pm 0.01$ & $0.17 \pm 0.00$ \\
10 & $14.41 \pm 2.07$ & $0.213 \pm 0.012$ & $0.177 \pm 0.021$ \\
& $28.27 \pm 1.67$ & $0.30 \pm 0.03$ & $0.24 \pm 0.01$ \\
\hline
\end{tabular}

\footnotetext{
$\mathrm{ND}=$ not detected.

a Non-defatted biomass.

b Defatted biomass.
}

considered to be a hydrolysis without using acid as catalyst. Further acid hydrolysis of the pretreated biomass reduced glucose concentration and raised inhibitors concentration. The cell wall of yeast may not be as rigid as that of lignocellulosic biomass of plant origin, which contains lignin. Thus yeast cell wall does not require subcritical water pretreatment. If yeast cell is pretreated, it results in too high degree of hydrolysis and significant sugar degradation.

\subsection{Effect of lipid extraction}

Y. lipolytica is an oleaginous microorganism which can accumulate large amount of lipid in its biomass. The effect of biomass lipid removal on the amount of glucose and inhibitors concentrations in the hydrolysate was investigated and the results are shown in Table 1 . It can be seen that glucose concentration is much lower in the hydrolysate of non-defatted biomass than in that of defatted biomass. The biggest difference in glucose concentration is $21.36 \mathrm{~g} / \mathrm{L}$ which occurred at an acid concentration of 6\%. Apparently the presence of lipid in biomass had negative effect on hydrolysis.

Harun et al. (2010) used the biomass of microalgae Chlorococum sp. as substrate for bioethanol production through fermentation by

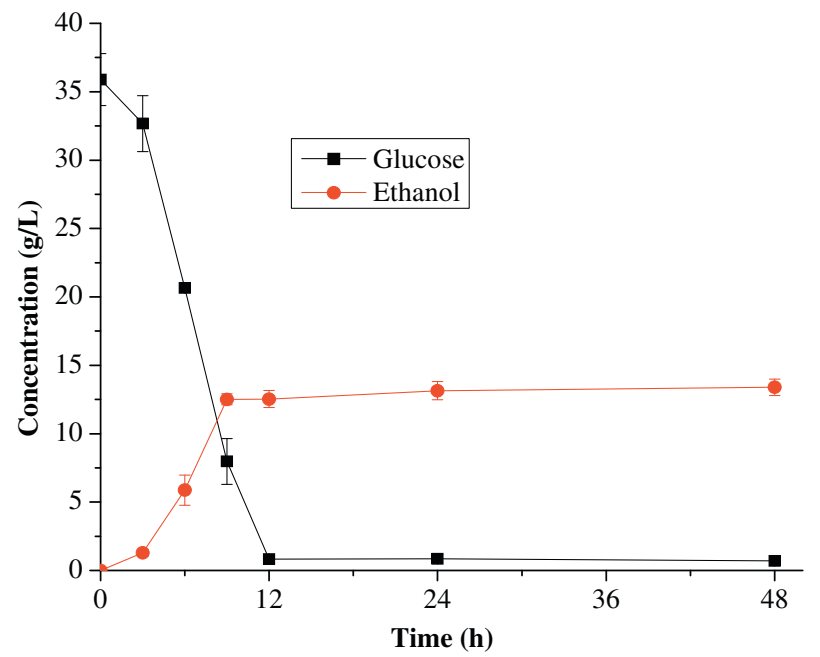

Fig. 5. Time courses of glucose and ethanol concentration in fermentation. 
Table 2

Sugar and ethanol concentrations using various biomass and with different pretreatment or hydrolysis methods.

\begin{tabular}{|c|c|c|c|c|c|}
\hline Microorganism & Pretreatment conditions & $\begin{array}{l}\text { Maximum glucose } \\
\text { conc. }(\mathrm{g} / \mathrm{L})\end{array}$ & $\begin{array}{l}\text { Maximum ethanol } \\
\text { conc. }(\mathrm{g} / \mathrm{L})\end{array}$ & Ethanol yield & Reference \\
\hline C. saccharoperbutylacetonicum & $\begin{array}{l}\text { Pretreatment with } \mathrm{H}_{2} \mathrm{SO}_{4} \text { or } \\
\mathrm{NaOH}, 90^{\circ} \mathrm{C}, 30 \mathrm{~min}\end{array}$ & 8.92 & 1.24 & $0.14 \mathrm{~g} / \mathrm{g}$ total sugar & Ellis et al. (2012) \\
\hline Chlamydomonas reinhardtii & $0.2 \%$ enzyme, $55^{\circ} \mathrm{C}, 30 \mathrm{~min}$ & 5.46 & 11.73 & $0.235 \mathrm{~g} / \mathrm{g}$ microalgae & Choi et al. (2010) \\
\hline Chlorella biomass & $\begin{array}{l}2 \% \mathrm{HCl}, 2 \% \mathrm{MgCl}_{2}, 180^{\circ} \mathrm{C} \text {, } \\
10 \mathrm{~min}\end{array}$ & 46.17 & 22.60 & $0.47 \mathrm{~g} / \mathrm{g}$ glucose & Zhou et al. (2011) \\
\hline Chlorococcum humicola & $1 \% \mathrm{H}_{2} \mathrm{SO}_{4}, 140{ }^{\circ} \mathrm{C}, 25 \mathrm{~min}$ & - & 7.2 & $0.52 \mathrm{~g} / \mathrm{g}$ microalgae & Harun and Danquah (2011) \\
\hline Yarrowia lipolytica Po1g & $6 \% \mathrm{H}_{2} \mathrm{SO}_{4}, 120^{\circ} \mathrm{C}, 60 \mathrm{~min}$ & 35.89 & 13.39 & $0.38 \mathrm{~g} / \mathrm{g}$ glucose & This study \\
\hline
\end{tabular}

Saccharomyces bayanus. A maximum ethanol concentration of $3.83 \mathrm{~g} / \mathrm{L}$ was obtained from $10 \mathrm{~g} / \mathrm{L}$ of lipid-extracted microalgae debris. The lipid-extracted microalgae gave 60\% higher ethanol concentration than the dried and intact microalgae. The high glucose concentration from lipid free biomass compared to biomass with lipid might be because the acid catalysis facilitated lipid removal prior to biomass hydrolysis for sugar production.

\subsection{Fermentation and ethanol production}

Every organism must find in its environment all nutrients required for energy generation and cellular synthesis. Factors such as carbon source, nitrogen source, $\mathrm{C} / \mathrm{N}$ molar ratio and culture conditions (temperature and $\mathrm{pH}$ ) have significant influences on cell growth, glucose consumption and ethanol accumulation of ethanol fermentation microorganism (Tsigie et al., 2011). For S. cerevisiae, the most important and common carbon source is glucose. If the $S$. cerevisiae used in fermentation is not genetically modified, it can use glucose, but not xylose and arabinose, as the carbon source and generate ethanol under anaerobic condition.

In this study, Ethanol $\operatorname{Red}^{\circledR}$ S. cerevisiae was employed in the fermentation process using $Y$. lipolytica biomass hydrolysate as the medium. Fig. 5 shows the time courses of glucose and ethanol concentration during fermentation. After $12 \mathrm{~h}$ most glucose was consumed while ethanol concentration reached $12.53 \mathrm{~g} / \mathrm{L}$. After $48 \mathrm{~h}$, $98.05 \%$ of glucose was consumed and final ethanol concentration was $13.39 \mathrm{~g} / \mathrm{L}$, corresponding to a yield of $0.38 \mathrm{~g}$ ethanol $/ \mathrm{g}$ glucose. The saccharification yield was $0.224 \mathrm{~g}$ glucose $/ \mathrm{g}$ dry biomass and the ethanol yield was $0.084 \mathrm{~g}$ ethanol $/ \mathrm{g}$ dry weight.

A maximum conversion of $0.115 \mathrm{~g}$ glucose/g corn fiber was reported when corn fiber was subjected to alkali pretreatment (Shrestha et al., 2010). Mathew et al. (2011) obtained a maximum glucose yield of $0.441 \mathrm{~g} / \mathrm{g}$ biomass when oilseed rape straw was subjected to alkali pretreatment. This study gave a maximum glucose yield of $0.224 \mathrm{~g} / \mathrm{g}$ dry biomass and productivity of $0.37 \mathrm{~g}$ glucose $/ \mathrm{h} / \mathrm{L}$.

\subsection{Comparison with other studies}

In this work, the glucose containing hydrolysate from Y. lipolytica biomass was used as the medium in the fermentation by $S$. cerevisiae with the final goal of producing ethanol. Table 2 shows comparison of results of this study with those reported in literature.

The highest ethanol concentration $(22.60 \mathrm{~g} / \mathrm{L})$ was obtained when Chlorella biomass was hydrolyzed $\left(2 \% \mathrm{HCl}\right.$ and $2.5 \% \mathrm{MgCl}_{2}$ ) to give a glucose concentration of $46.17 \mathrm{~g} / \mathrm{L}$ in the hydrolysate. On the other hand, acid or base pretreatment of Clostridium saccharoperbutylacetonicum biomass resulted in $8.92 \mathrm{~g} / \mathrm{L}$ glucose and led to $1.24 \mathrm{~g} / \mathrm{L}$ maximum ethanol production. In this study, the a glucose concentration of $35.89 \mathrm{~g} / \mathrm{L}$ was obtained when defatted biomass was hydrolyzed with $6 \%$ sulfuric acid at $120^{\circ} \mathrm{C}$ for $1 \mathrm{~h}$.
After $48 \mathrm{~h}$ fermentation, the ethanol concentration achieved was $13.39 \mathrm{~g} / \mathrm{L}$.

\section{Conclusion}

Under optimum conditions $\left(120^{\circ} \mathrm{C}\right.$, biomass to acid solution ratio of 1:10, 6 wt.\% sulfuric acid), the hydrolysate contained $35.89 \mathrm{~g} /$ L glucose. Temperature was the most important parameter that affected hydrolysis. Glucose was the predominant sugar in the hydrolysate indicating its availability for microbial fermentation. During fermentation, glucose concentration decreased to $0.7 \mathrm{~g} / \mathrm{L}$ and ethanol concentration reached $13.39 \mathrm{~g} / \mathrm{L}$ after $48 \mathrm{~h}$ and $98.05 \%$ of glucose was consumed; corresponding to a yield of $0.38 \mathrm{~g}$ ethanol $/ \mathrm{g}$ glucose. The saccharification yield was $0.224 \mathrm{~g}$ glucose $/ g$ dry weight and the ethanol yield was $0.084 \mathrm{~g}$ ethanol/g dry weight.

\section{Acknowledgements}

This work was funded by National Science Council of Taiwan with Grant number NSC-98-2221-E-011-046-MY3.

\section{References}

Balat, M., 2011. Production of bioethanol from lignocellulosic materials via the biochemical pathway: a review. Energy Conversion and Management 52 (2), 858-875.

Bellido, C., Bolado, S., Coca, M., Lucas, S., González-Benito, G., García-Cubero, M.T., 2011. Effect of inhibitors formed during wheat straw pretreatment on ethanol fermentation by Pichia stipitis. Bioresource Technology 102 (23), 10868-10874.

Brennan, L., Owende, P., 2010. Biofuels from microalgae-a review of technologies for production, processing, and extractions of biofuels and co-products. Renewable and Sustainable Energy Reviews 14 (2), 557-577.

Chandel, A.K., Kapoor, R.K., Singh, A., Kuhad, R.C., 2007. Detoxification of sugarcane bagasse hydrolysate improves ethanol production by Candida shehatae NCIM 3501. Bioresource Technology 98 (10), 1947-1950.

Chen, W.-H., Tu, Y.-J., Sheen, H.-K., 2010. Impact of dilute acid pretreatment on the structure of bagasse for bioethanol production. International Journal of Energy Research 34 (3), 265-274

Choi, S.P., Nguyen, M.T., Sim, S.J., 2010. Enzymatic pretreatment of Chlamydomonas reinhardtii biomass for ethanol production. Bioresource Technology 101 (14), 5330-5336.

Conde-Mejía, C., Jiménez-Gutiérrez, A., El-Halwagi, M., 2012. A comparison of pretreatment methods for bioethanol production from lignocellulosic materials. Process Safety and Environmental Protection 90 (3), 189-202.

del Campo, I., Alegría, I., Zazpe, M., Echeverría, M., Echeverría, I., 2006. Diluted acid hydrolysis pretreatment of agri-food wastes for bioethanol production. Industrial Crops and Products 24 (3), 214-221.

Ellis, J.T., Hengge, N.N., Sims, R.C., Miller, C.D., 2012. Acetone, butanol, and ethanol production from wastewater algae. Bioresource Technology 111, 491-495.

Fickers, P., Marty, A., Nicaud, J.M., 2011. The lipases from Yarrowia lipolytica: genetics, production, regulation, biochemical characterization and biotechnological applications. Biotechnology Advances 29 (6), 632-644.

Goh, C.S., Lee, K.T., Bhatia, S., 2010. Hot compressed water pretreatment of oil palm fronds to enhance glucose recovery for production of second generation bioethanol. Bioresource Technology 101 (19), 7362-7367.

Gupta, R., Sharma, K.K., Kuhad, R.C., 2009. Separate hydrolysis and fermentation (SHF) of Prosopis juliflora, a woody substrate, for the production of cellulosic ethanol by Saccharomyces cerevisiae and Pichia stipitis-NCIM 3498. Bioresource Technology 100 (3), 1214-1220. 
Hahn-Hägerdal, B., Galbe, M., Gorwa-Grauslund, M.F., Lidén, G., Zacchi, G., 2006. Bio-ethanol - the fuel of tomorrow from the residues of today. Trends in Biotechnology 24 (12), 549-556.

Harun, R., Danquah, M.K., 2011. Influence of acid pre-treatment on microalga biomass for bioethanol production. Process Biochemistry 46 (1), 304-309.

Harun, R., Danquah, M.K., Forde, G.M., 2010. Microalgal biomass as a fermentation feedstock for bioethanol production. Journal of Chemical Technology and Biotechnology 85 (2), 199-203.

Jeong, T.S., Choi, C.H., Lee, J.Y., Oh, K.K., 2012. Behaviors of glucose decomposition during acid-catalyzed hydrothermal hydrolysis of pretreated Gelidium amansii. Bioresource Technology 116, 435-440.

Jeong, T.S., Kim, Y.S., Oh, K.K., 2011. Two-stage acid saccharification of fractionated Gelidium amansii minimizing the sugar decomposition. Bioresource Technology 102 (22), 10529-10534.

John, R.P., Anisha, G.S., Nampoothiri, K.M., Pandey, A., 2011. Micro and macroalga biomass: a renewable source for bioethanol. Bioresource Technology 102 (1) 186-193.

Lebeau, T., Jouenne, T., Junter, G.A., 1997. Simultaneous fermentation of glucose and xylose by pure and mixed cultures of Saccharomyces cerevisiae and Candida shehatae immobilized in a two-chambered bioreactor. Enzyme and Microbial Technology 21 (4), 265-272.

Lee, J.-Y., Yoo, C., Jun, S.-Y., Ahn, C.-Y., Oh, H.-M., 2010. Comparison of several methods for effective lipid extraction from microalgae. Bioresource Technology 101 (Suppl. 1), S75-S77.

Lenihan, P., Orozco, A., O'Neill, E., Ahmad, M.N.M., Rooney, D.W., Walker, G.M., 2010. Dilute acid hydrolysis of lignocellulosic biomass. Chemical Engineering Journal 156 (2), 395-403.

Mathew, A.K., Chaney, K., Crook, M., Humphries, A.C., 2011. Alkaline pre-treatmen of oilseed rape straw for bioethanol production: evaluation of glucose yield and pre-treatment energy consumption. Bioresource Technology 102 (11), 65476553

Miller, G.L., 1959. Use of dinitrosalicylic acid reagent for determination of reducing sugars. Analytical Chemistry 31 (3), 426-428.

Miyafuji, H., Danner, H., Neureiter, M., Thomasser, C., Bvochora, J., Szolar, O., Braun, R., 2003. Detoxification of wood hydrolysates with wood charcoal for increasing the fermentability of hydrolysates. Enzyme and Microbial Technology 32 (3-4), 396-400.

Mohamed, A.R., Mohammadi, M., Darzi, G.N., 2010. Preparation of carbon molecular sieve from lignocellulosic biomass: a review. Renewable and Sustainable Energy Reviews 14 (6), 1591-1599.

Palmarola-Adrados, B., Chotěborská, P., Galbe, M., Zacchi, G., 2005. Ethanol production from non-starch carbohydrates of wheat bran. Bioresource Technology 96 (7), 843-850.

Palmqvist, E., Hahn-Hägerdal, B., 2000. Fermentation of lignocellulosic hydrolysates. II: Inhibitors and mechanisms of inhibition. Bioresource Technology 74 (1), 25-33.

Sarkar, N., Ghosh, S.K., Bannerjee, S., Aikat, K., 2012. Bioethanol production from agricultural wastes: an overview. Renewable Energy 37 (1), 19-27.

Schädel, C., Blöchl, A., Richter, A., Hoch, G., 2010. Quantification and monosaccharide composition of hemicelluloses from different plant functional types. Plant Physiology and Biochemistry 48 (1), 1-8.

Shrestha, P., Khanal, S.K., Pometto III, A.L., van Leeuwen, J., 2010. Ethanol production via in situ fungal saccharification and fermentation of mild alkali and steam pretreated corn fiber. Bioresource Technology 101 (22), 8698-8705.

Sluiter, A., Hames, B., Ruiz, R., Scarlata, C., Sluiter, J., Templeton, D., Crocker, D., 2008. Determination of Structural Carbohydrates and Lignin in Biomass: Laboratory Analytical Procedure (LAP). Technical Report NREL/TP-510-12618, National Renewable Energy Laboratory, Department of Energy, USA.

Tsigie, Y.A., Wang, C.-Y., Truong, C.-T., Ju, Y.-H., 2011. Lipid production from Yarrowia lipolytica Po1g grown in sugarcane bagasse hydrolysate. Bioresource Technology 102 (19), 9216-9222.

Tsigie, Y.A., Huynh, L.H., Ahmed, I.N., Ju, Y.-H., 2012a. Maximizing biodiese production from Yarrowia lipolytica Po1g biomass using subcritical water pretreatment. Bioresource Technology 111, 201-207.

Tsigie, Y.A, Wang C.Y, Kasim, N.S., Diem, Q.D., Huynh, L.H., Ho, Q P., Truong C.T. Ju, Y.H., 2012b. Oil Production from Yarrowia lipolytica Po1g using rice bran hydrolysate. Journal of Biomedicine and Biotechnology 2012, 378384.

Zhou, N., Zhang, Y., Wu, X., Gong, X., Wang, Q., 2011. Hydrolysis of Chlorella biomass for fermentable sugars in the presence of $\mathrm{HCl}$ and $\mathrm{MgCl}_{2}$. Bioresource Technology 102 (21), 10158-10161. 